\title{
THE MAP OF ROMAN DACIA IN THE RECENT STUDIES
}

\section{Szabó Csaba}

DOI: http://dx.doi.org/10.14795/j.v1i1.11

ISSN 2360 - 266X

ISSN-L 2360 - 266X
Abstract: In this paper the author presents the evolution of the cartographic representation of Roman Dacia in the recent studies of archaeology and ancient history, focusing especially on the lacunas and main problems of foreign (nonRomanian) maps, appeared in the last decade in the international scholarship.
$\mathbf{M}$ apping the Roman Empire with its provinces was always an important task not only for scholars, travelers but even for the ancient people who lived in that environment ${ }^{1}$. Recent studies on Roman topography $^{2}$, centuriation (centuriatio) ${ }^{3}$ and modern cartography ${ }^{4}$ changed radically our knowledge and especially the visual perception of the Roman Empire, creating new, more detailed and accurate maps of every province. The new international and regional projects on the studies of the Roman Limes ${ }^{5}$ urged also the creation of new and much more adequate maps of the Roman Empire and it's provinces. Nevertheless, the cartographic representation of Roman Dacia in the foreign and Romanian literature is still very rhapsodic and full with major mistakes.

By presenting the latest results of the research, this paper will try to answer on a very simple, but uncomfortable question: why we don't have a standard map of Roman Dacia?

\section{Redrawing Dacia: new results}

The recent archaeological, topographical and geophysical studies in the last decade changed our knowledge about the Limes Dacicus and also the internal administration and centuriation of Roman Dacia.

\footnotetext{
${ }^{1}$ Talbert 2010, 252-273.

2 Talbert 2012, 163-193. Fodorean 2013, 62-63.

${ }^{3}$ Marcu - Cupcea 2011, 543-560.

${ }^{4}$ In the last decade there were many initiatives for modern cartographic projects, mapping the Roman Empire. The most important are: Pleiades Project (http://pleiades.stoa.org/), Stanford Orbis Project (http://isaw.nyu.edu/exhibitions/space/orbis.html), Barrington Atlas of Greek and Roman World (digitized version from 2012 - http://pelagios-project.blogspot.ro/2012/09/adigital-map-of-roman-empire.html).

${ }^{5}$ Danube Limes Project (http://www.danube-limes.eu/) or the Roman Limes Route Project (http:// www.limesdacicus.ro/).
} 
First of all, the inner administration and internal structure of the province are better known, not only due to the chronological details but also by the new topographical elements on the new maps ${ }^{6}$. Our knowledge about the centuriation and the local topography of many Roman settlements (especially the civil town of Ulpia Traiana Sarmizegetusa?, Apulum $^{8}$, the auxiliary fortress and the civil town of Porolissum $^{9}$, Arcobadara ${ }^{10}$, Napoca ${ }^{11}$ and Potaissa ${ }^{12}$ ) show also a fast evolution. Even the highly neglected or just superficially analyzed ${ }^{13}$ rural world of the province represents the focus point of some modern researches ${ }^{14}$. The regional studies of some small topographical and geographical units expended also our knowledge and changed some aspects of the cartographic look of Dacia. However, the internal structure and the inner centuration of the province is still not well - known and marked totally conventional, schematically on every Romanian maps ${ }^{15}$.

Beside the internal, topographical and toponimical changes and researches the most important progression was made is the Roman Limes studies.

Each side (especially the Western, Northern and Eastern) of the Limes Dacicus is researched and changed. The most important changes appeared especially in the Western part of the Limes, where the international projects ${ }^{16}$ from the both side of the Limes (Barbaricum ${ }^{17}$ and province too) redrawn the conventional line of the Western border of the province, traditionally marked on maps till Partiscum. The new methodology and field works revealed the possible vexillation fortresses in the Banat area ${ }^{18}$, possibly closing an old, secular problem in the historiography. The new researches regarding the archaeological material of that area proved also the plausibility of the Limes - studies in this area ${ }^{19}$.

The North - Western part of the limes is also well researched. Modern researches in the auxiliary fortresses of Dacia Porolissensis (Bologa ${ }^{20}$, Buciumi $^{21}$, Porolissum ${ }^{22}$ ) had important contributions to the better understanding of this area. The epigraphic project ${ }^{23}$ and the intensive field works

\footnotetext{
${ }^{6}$ For the historiography on this topic see: Ardevan 2010, 279-289. About the new toponims see: Dana - Nemeti 2012, 431-437.

${ }^{7}$ Marcu - Cupcea 2011, 543-560.

${ }^{8}$ New projects regarding the topography of the civilian towns: Arhitectura romană la Apulum. Propuneri de reconstituire a evoluţiei urbane cu ajutorul aplicaţiilor grafice 3D. Ph. D. thesis - Teodor Muntean, University of Iasi and Apulum Project - Urban and Cultic space in Apulum (http://diam.uab.ro/index. php?s=10\&p=94).

9 Döhner 2011, 93-103, Opreanu - Lăzărescu - Ștefan 2013a, 83-107, Opreanu - Lăzărescu - Ștefan 2013b,

509-524.

${ }^{10}$ Bărbulescu - Nemeti 2008, 107-118.

${ }^{11}$ Marcu - Rădeanu 2013.

12 Fodorean 2013, 42-49.

${ }^{13}$ Mitrofan 1993, 169-173, Popa 2003

14 Oltean 2004, 143-165.

${ }^{15}$ About the new researches regarding the inner - administrational structure of the province, see: Ardevan 2010, 288.

${ }^{16}$ Nemeth 2005, Nemeth 2011.

${ }^{17}$ Kulcsár - Istvánovits 2009, 355-369.

${ }^{18}$ About the methodology: Nemeth 2011, 28-41. The new maps: 106-7.

${ }^{19}$ Cronica 2013, 124, 220-223, Grumeza 2013, 413-435.

${ }^{20}$ Cronica 2013, 151-152, Marcu, - Cupcea 2013, 569-589.

${ }^{21}$ Găzdac 2012.

22 See note nr.9.

${ }^{23}$ Written Heritage of the Roman Civilization in Northern Romania. Webpage:

http://hiphi.ubbcluj.ro/written_heritage/index.html
}

of regional museums ${ }^{24}$ marked also the new "outlook" of the province of Dacia and the topography of it.

The new projects of Limes Dacicus Orientalis (LIDOR), Roman Limes Route Project and Graniţa romană în estul provinciei Dacia ${ }^{25}$ deal with the redrawing of the Eastern Limes of Dacia. Due to the intensive field work, geophysical surveys and systematic excavations, our knowledge enriched significantly about the most poorly researched part of the Dacian border ${ }^{26}$.

The border of Dacia Inferior (and later, Dacia Malvensis) was always a very sensitive topic in historiography. The most disputed part of it - the South - Eastern border of the province (so called Limes Alutanus and Transalutanus) on which exists only few modern works and researches ${ }^{27}$. The majority of the fortresses are not well researched in this area.

Summarizing the latest researches and their results, we can conclude that the inner and outer topography of Roman Dacia is investigated after the latest and most modern, interdisciplinary methods, practically redrawing the old map of the province.

\section{New maps, old problems}

Although the above presented results would require a new, revised map of Dacia, we can observe a huge variety of wrong maps in academic and popularizing works too. It is important to separate the Romanian academic studies from the international ones, because in the last period we can see a different tendency in the representation of Dacia.

For a long period, the map appeared in the TIR (Tabula Imperii Romani L 34) and in the well - known manual of Mihai Macrea ${ }^{28}$ was used as the prototype for the representation of Dacia. The main problems appeared on these maps was the inadequate representation of the Limes Dacicus Occidentalis and the Limes Transalutanus. All the maps appeared before 2005 used this two version - or rare, even worst maps, where the ancient province covers the actual territory of Romania ${ }^{29}$. The publications of Professor Nicolae Gudea marked for decades the representation of Dacia especially in the field of military history ${ }^{30}$.

In 2005 in Romania appeared the first modern atlas of Roman Dacia ${ }^{31}$, with many thematic maps. Even if the detailed maps are very useful in the map, the small versions are similar to the maps of $\mathrm{Macrea}^{32}$, presenting the Limes Dacicus till Partiscum and the Limes Transalutanus very schematically. The inner limits of the sub - provinces are presented also very superficial. The small maps are in fact the same representation of Dacia made by professor Ioan Piso in $1993^{33}$ which is only slightly different the maps known from

\footnotetext{
${ }^{24}$ Especially the Museum of Sălaj County and Museum of Bistrița Năsâud.

${ }^{25}$ http://limes.rdsweb.ro/descriere_en.html

${ }^{26}$ About the results, see: Pánczél et ali 2011, 173-181, Cronica 2013, 36-7,

Pánczél et ali 2012, 105-117.

${ }^{27}$ Teodor 2013

${ }^{28}$ Macrea 1969, 35-39.

${ }^{29}$ Carbonara 2012, Smith 2012, 139. subnote.

${ }^{30}$ Gudea 1997, 9-15. The author use the same maps even in his new book:

Gudea - Lobüscher 2006. A critical

review of these representations: Visy 2009, 115-127.

${ }^{31}$ Bărbulescu 2005

${ }^{32}$ Review of the book: Găzdac 2006, 142-148.

${ }^{33}$ Piso $1993,7$.
} 
the earlier works. The representation of Roman Dacia was first of all an ideological - historical and also, rivalry question in the Romanian academic field, simply followed and superficially copied by the international public ${ }^{34}$.

After 2005 the use of a new representation of Dacia was provoked both from Romanian and international voices ${ }^{35}$ but the situation seems to be almost the same.

There are three main categories of maps used today: the revised map of Dacia appeared in the Romanian and international literature ${ }^{36}$, the old and wrong map of Dacia still used by highly quoted or important Romanian and foreign scholars and works ${ }^{37}$ and the maps used in popularizing works or conference presentations ${ }^{38}$. Many of the most recently published maps use the same mistakes neglecting the new results of topography, landscape archaeology and Limes studies.

\section{Conclusion}

The representation of Dacia in the Romanian and international studies and popularizing works has a long and problematic historiography. Even if the archaeological excavations and interdisciplinary studies redrawn the inner and outer border and topography of Dacia, the new maps published after 2005 often presents the same mistakes and features as the old maps, drawn in a politically influenced period.

For the next generations will be very important to use an adequate map of Roman Dacia and the Roman Empire.

\section{Bibliography}

\section{ARDEVAN 2010}

Ardevan, Radu, La divisione amministrativa della Dacia Romana nella storiografia. In: Zerbini, Livio (ed.), Roma e le province del Danubio. Atti del I Convegno Internazionale. Rubbettino, 2010, 279-289

ARDEVAN - ZERBINI 2013

Ardevan, Radu - Zerbini, Livio, I romani nelle province danubiane. In: Forma Urbis. Anno XVIII. nr. 11., November 2013, 6.

BĂRBULESCU 2005

Bărbulescu, Mihai (ed.), Atlas - dicționar al Daciei romane. Tribuna, 2005

BĂRBULESCU - NEMETI 2008

Bărbulescu, Mihai - Nemeti, Sorin, Territorium Arcobadarense. In: Ephemeris Napocensis XVII - XVIII, 2008, 107-118.

CARBONARA 2012

Carbonara, Antonio, La Roma di Benito Mussolini: Via dei Fori Imperiali e la carte geografiche. In: Corriere di Puglia. 2012, July, 20 CRONICA 2013

Cronica cercetărilor arheologice. Campania 2012. Ministerul Culturii - Muzeul Olteniei, Craiova, 2013

\footnotetext{
${ }^{34}$ Petculescu's map (school of Bucuresti) from 1999 is almost totally neglected by many of the Romanian

scholars: Visy 2009, 124.

${ }^{35}$ Nemeth 2005, Visy 2009.

${ }^{36}$ Johne 2008, I. map (Die Römische Reich in 235), Visy 2010, 83- 93,

Mladenovici 2012, (map. I. The Central Balkans in the Roman times), Găzdac 2012, fig. I.

${ }^{37}$ Zmudzinski 2007, 24, Marinescu, 2010, 75, De Sena 2011, 963-972.

Fig. I., Opreanu 2011, 125-136, fig. I., Weiss 2011, 147. Fig. I.

${ }^{38}$ Ardevan - Zerbini 2013, 6.
}

\section{DANA - NEMETI 2012}

Dana, Dan - Nemeti, Sorin, Ptolémée et la toponymie de la Dacie. In: Classica et Christiana VII, 2012, 431-437

\section{DE SENA 2011}

De Sena, Eric, Porolissum and the late - Roman and immediate post - Roman economy of Dacia (225-375): the evidence of pottery. In: Menchelli, Simoneta - Santoro, Sara, LRCW 3: late Roman coarse wares, cooking wares and amphorae in the Mediterranean: comparison between Western and Eastern Mediterranean. Oxford, 2011, 963-972.

DÖHNER 2011

Döhner, Gregor et ali, Neue Forschungen in Kastell von Porolissum. In: Kölner und Bonner Archaeologica. 2011, 93-103. FODOREAN 2013

Fodorean, Florin, The topography and the landscape of Roman Dacia. BAR International Series 2501, 2013

GĂZDAC 2006

Găzdac, Cristian, Recenzie. In: Studia Universitatis Babeş Bolyai, Historia 51., I., 2006, 142-148.

GĂZDAC 2012

Găzdac, Cristian, The Roman Auxiliary Fort at Buciumi (Roman Dacia, Romania). Coins in archaeological context. BAR International Series, 2381, Oxford, 2012

GUDEA 1997

Gudea, Nicolae, Die Dakische Limes. Materialen zu seiner Geschichte. Jahrbuch der Römich - Germanischen Zentralmuseums Mainz. 44, 1997

GUDEA - LOBÜSCHER 2006

Gudea, Nicolae - Lobüscher, Thomas, Dacia. Eine römische Provinz zwischen Karpaten und Schwarzem Meer. Philipp von Zabern Verlag, 2006.

GRUMEZA 2013

Grumeza, Lavinia, Animal inhumation within settlements during the Sarmatian period on the Western plain. In: ArheoVest, nr. I.: In memoriam Liviu Măruia - interdisciplinaritate în arheologie şi istorie, Timişoara, 7 decembrie, 2013, 413-435.

JOHNE 2008

Klaus - Hartmann, Udo - Gerhardt, Thomas, Die Zeit der Soldatenkaiser. Berlin, 2008

KULCSÁR - ISTVÁNOVITS 2009

Kulcsár Valéria - Istvánovits Eszter, Roman Age Barbarian Pottery Workshops in the Great Hungarian Plain. In: Drehscheibentöpferei im Barbaricum Technologietransfer und Professionalisierung eines Handwerks am Rande des Römischen Imperiums.: Akten der Internationalen Tagung in Bonn vom 11. bis 14. Juni 2009. Bonn, 355-369.

MACREA 1969

Macrea, Mihail, Viața cotidiană în Dacia romană. Editura Academiei, Bucureşti, 1969

MARCU - CUPCEA 2011

Marcu, Felix - Cupcea, George, The topography of Colonia Ulpia Traiana Augusta Dacica Sarmizegetusa and the first centuriation in Dacia. In: Archaeologisches Korrespondenzblatt, Jahrgang 41, 2011, Heft 4, $543-560$.

MARCU - CUPCEA 2013

Marcu, Felix - Cupcea, George,Topografia limesului de Nord Vest al Daciei în zona castrului de la Bologa. In: ArheoVest, nr. I.: In memoriam Liviu Măruia - interdisciplinaritate în arheologie şi istorie, Timişoara, 7 decembrie, 2013, 569-589.

MARCU - RĂDEANU 2013

Marcu, Felix - Cupcea, George - Rădeanu, Virginia, Topografia arheologică a orașului Napoca. Presentation ont he conference organized by the History Museum of Turda, 18 October, 2013.

MARINESCU 2010

Marinescu, Lucia, Arte romana in Dacia. In: Ori antichi della Romania prima e dopo Traiano: (mostra Roma, 17 
dicembre 2010-3 aprile 2011) mostra e catalogo a cura di Ernest Oberländer-Târnoveanu, Lucrezia Ungaro. Milano, 2010.

MLADENOVICI 2012

Mladenovici, Dragana, Urbanism and Settlement in the Roman Province of Moesia Superior. BAR International Series 2367, 2012.

MITROFAN 1993

Mitrofan, Ioan, Les villae rusticae dans la Dacie romaine. In: $L a$ politique édilitaire dans les provinces de l'Empire Romain III. Cluj Napoca, 1993, 169-173

NEMETH 2005

Nemeth, Eduard (ed.), Limes Dacicus Occidentalis. Die Befestigungen in Westen Dakiens vor und nach der römischen Eroberung. Cluj - Napoca, Editura Mega, 2005

NEMETH 2011

Nemeth, Eduard - Fodorean, Florin - Matei, Dan - Blaga, Dragos, Der südwestlische Limes des römischen Dakien. Strukturen und Landschaft. Editura Mega, 2011

OLTEAN 2004

Oltean, Ioana, Rural settlement in Roman Dacia: some considerations. In: Hanson, W. - Haynes, Ian (eds.), Roman Dacia. The making of a provincial society. JRA Supplementum, Portsmouth, 2004, 143-165.

OPREANU 2011

Opreanu, Coriolan - Horaţiu, The Barbarian and Roman Dacia. War, trade and cultural interaction. In: De Sena, Eric (ed.), The Roman Empire and beyond. Archaeological and historical research on the Romans and Native cultures in Central Europe. BAR International Series 2236, 2011, 125-136,

OPREANU - LĂZĂRESCU - ŞTEFAN 2013A

Opreanu, Coriolan - Lăzărescu, Vlad - Ştefan, Dan, Noi cercetări la Porolissum. In: Analele Banatului. Arheologie şi Istorie. XXI. 2013, 83-107

OPREANU - LĂZĂRESCU - ŞTEFAN 2013B

Opreanu, Coriolan - Lăzărescu, Vlad - Ştefan, Dan, Recent geophysical surveys of Porolissum. In: ArheVest, nr. I.: In memoriam Liviu Măruia - interdisciplinaritate în arheologie şi istorie, Timişoara, 7 decembrie, 2013, 509-524.

PÁNCZÉL ET ALI 2011

Pánczél Szilamér et ali, Dacia keleti határának régészeti kutatása. In: Visy Zsolt (ed.), A Danube Limes program régészeti kutatásai 2008 és 2011 között. Pécs, 2011, 173-181.

PÁNCZÉL ET ALI 2012

Pánczél Szilamér et ali, Updating our knowledge about the Roman fort from Brâncoveneşti, Mureş County. In: Marisia XXXII, 2012, 105-117.

PISO 1993

Piso, Ioan, Fasti Provinciae Daciae. I. Die senatorischen Amtsträger. Ed. Habelt, Bonn 1993

POPA 2003

Popa, Dumitru, Villae, vici, pagi. Aşezările rurale din Dacia romană intracarpatică. 2003

SMITH 2012

Smith, Denis - Mack, Mussolini. Storia, 2012

TALBERT 2010

Talbert, Richard, The Roman Worldview - beyond recovery? In: Raaflaub, Kurt - Talbert, Richard, Geography and Etnography: Perception of the World in pre - modern societies. Blackwell, 2010, 252-273

TALBERT 2012

Talbert, Richard, Urbs Roma to Urbis Romanus: Roman mapping on the grand scale. In: Talbert, Richard (ed.), Ancient Perspectives: maps and their places in Ancient Mesopotamia, Egypt, Greece and Rome. Chicago University Press, 2012, 163-193

\section{TEODOR 2013}

Teodor, Eugen, Uriaşul invizibil: Limes Transalutanus. O reevaluare la sud de râul Argeş. Cetatea de Scaun, 2013

VISY 2009

Visy Zsolt, Mapping the SW Limes of Dacia. In: Hanson, William (ed.), The Army and Frontiers of Rome. Portsmouth, Rhode Island, 2009, 115-127.

VISY 2010

Visy Zsolt, The connections between Pannonia and Dacia in a historical context. In: Angelescu, Mircea et ali (eds.) Antiquitas Istro - Pontica. Mega, Cluj, 2010, 83- 93.

WEISS 2011

Weiss, Dani, Influence and observation: towards a more Concrete understanding of the Roman - Dacian Limes. In: De Sena 2011, 138-150.

\section{ZMUDZINSKI 2007}

Zmudzinski Mateusz, Gospodarka w rzymskiej prowincji Dacji Superior. Wroclaw, 2007 


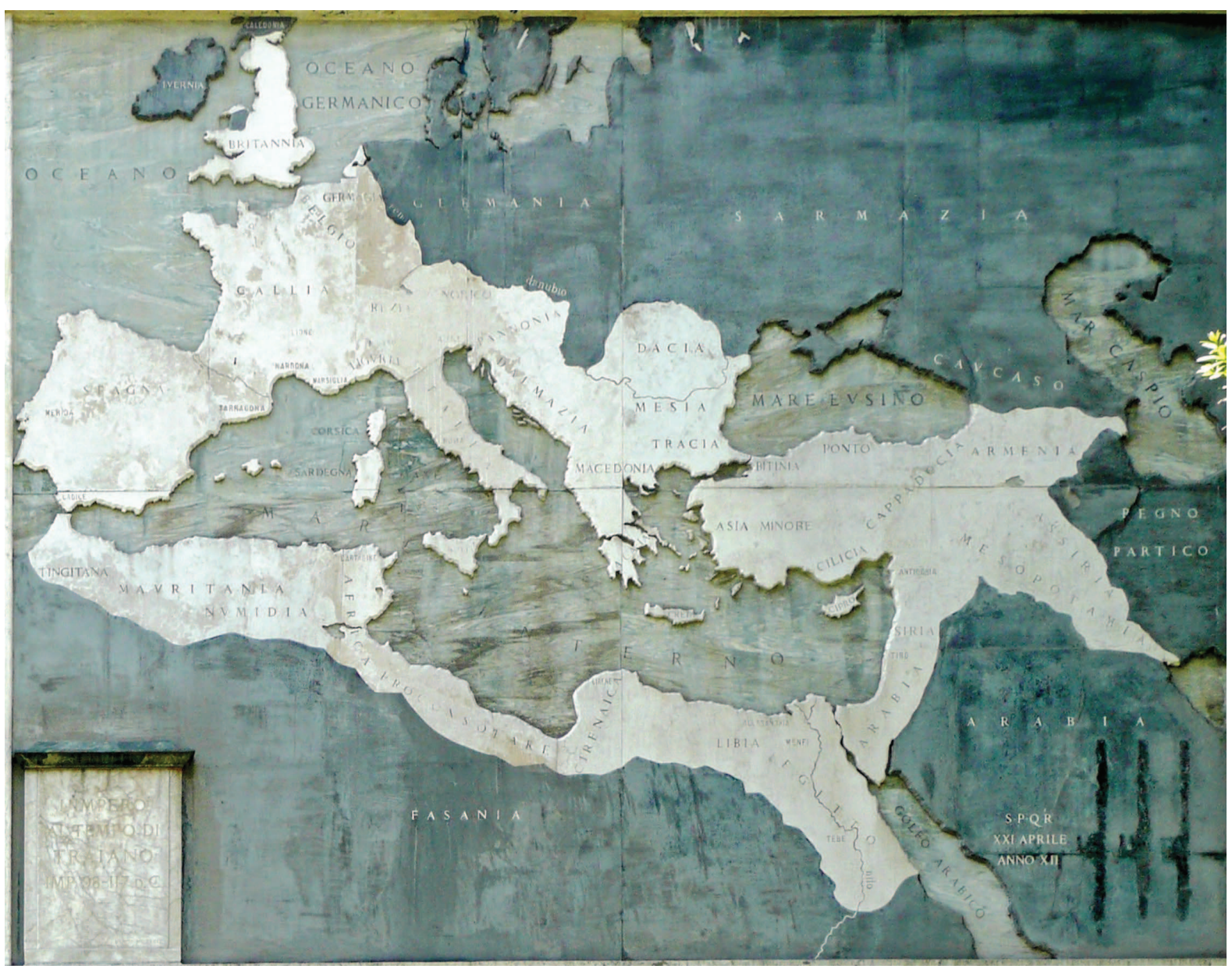

Mussolini's marble map (Via dei Fori Imperiali, Rome)

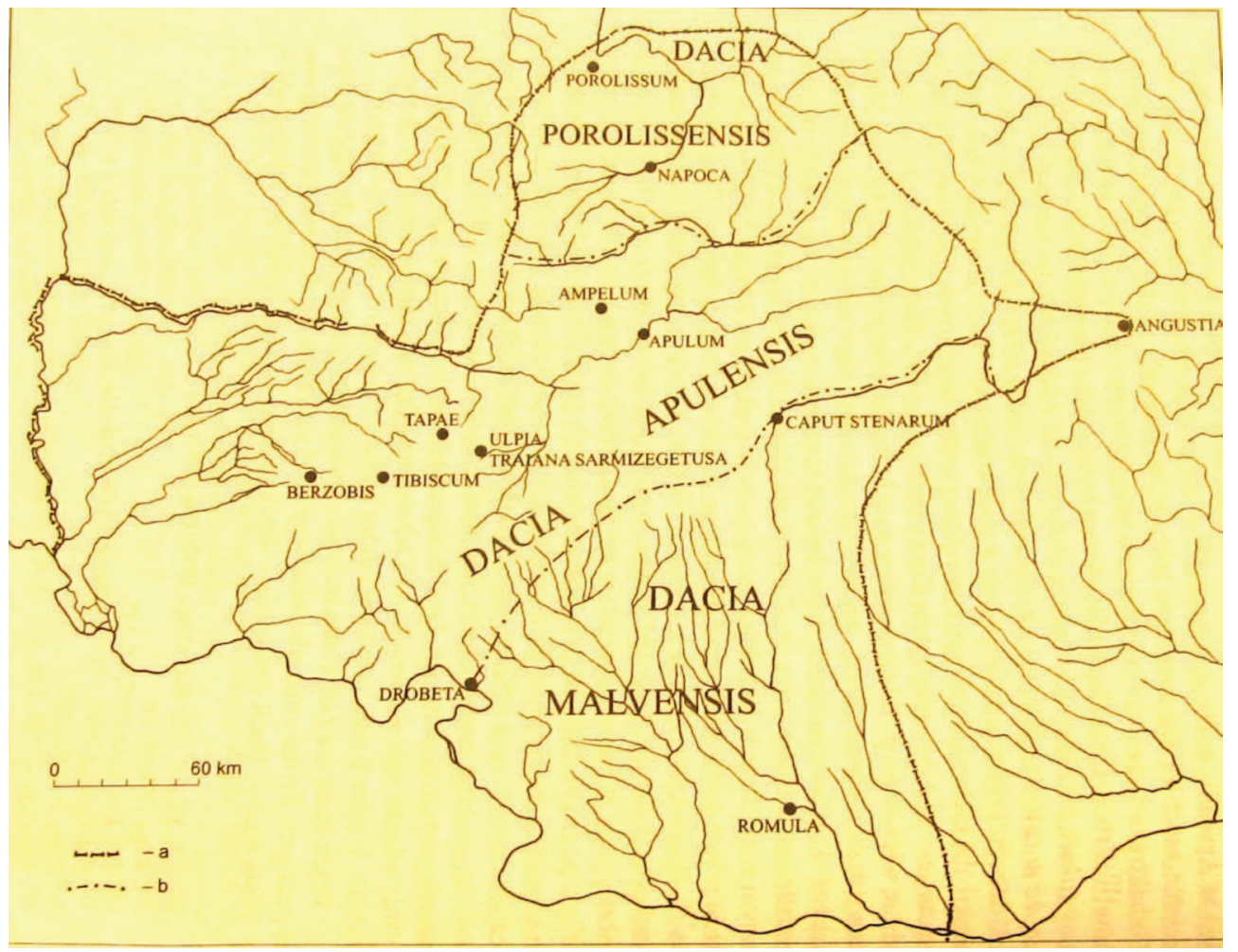

Zmudzinski 2007, 24. 


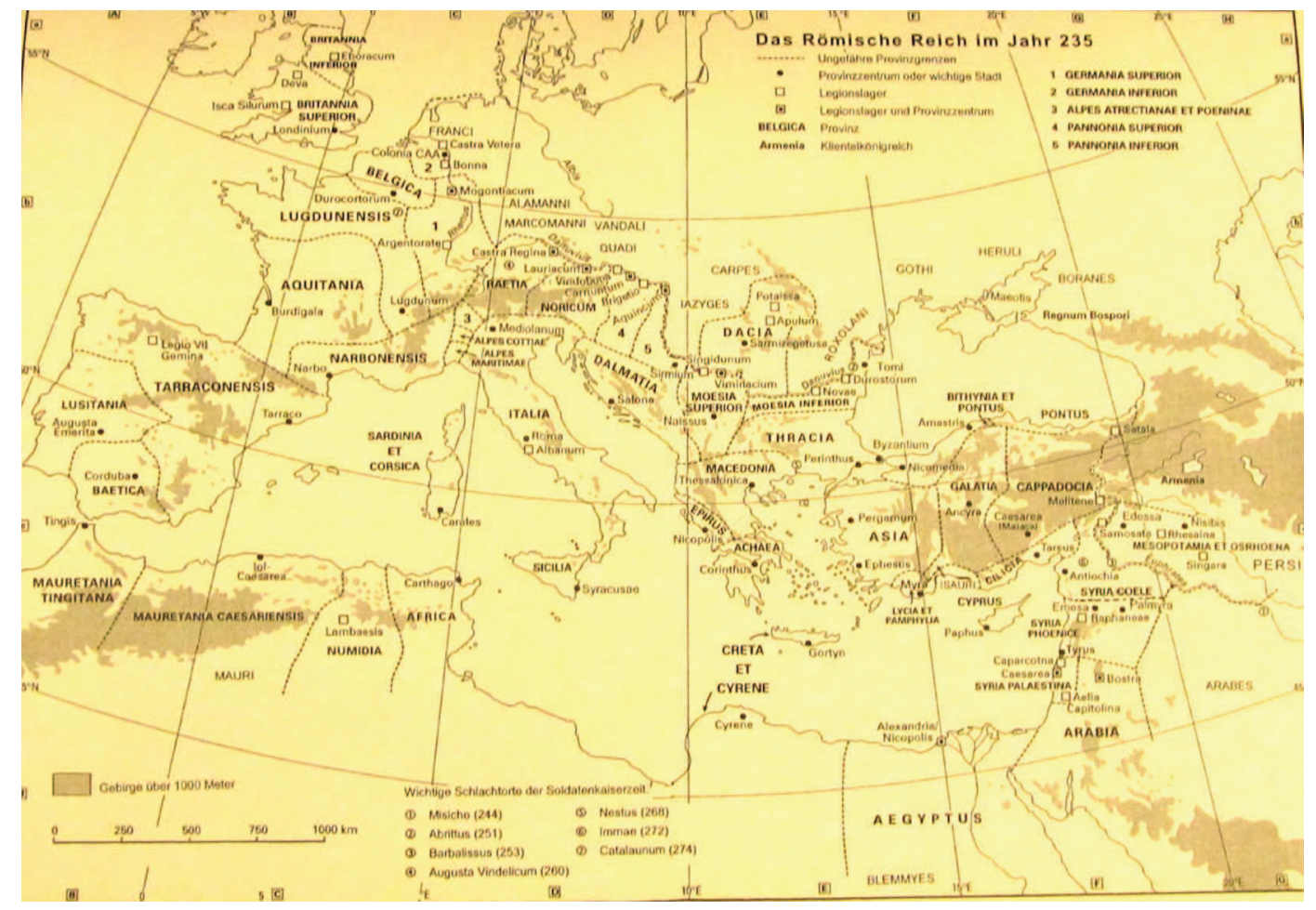

Johne 2008, I. map

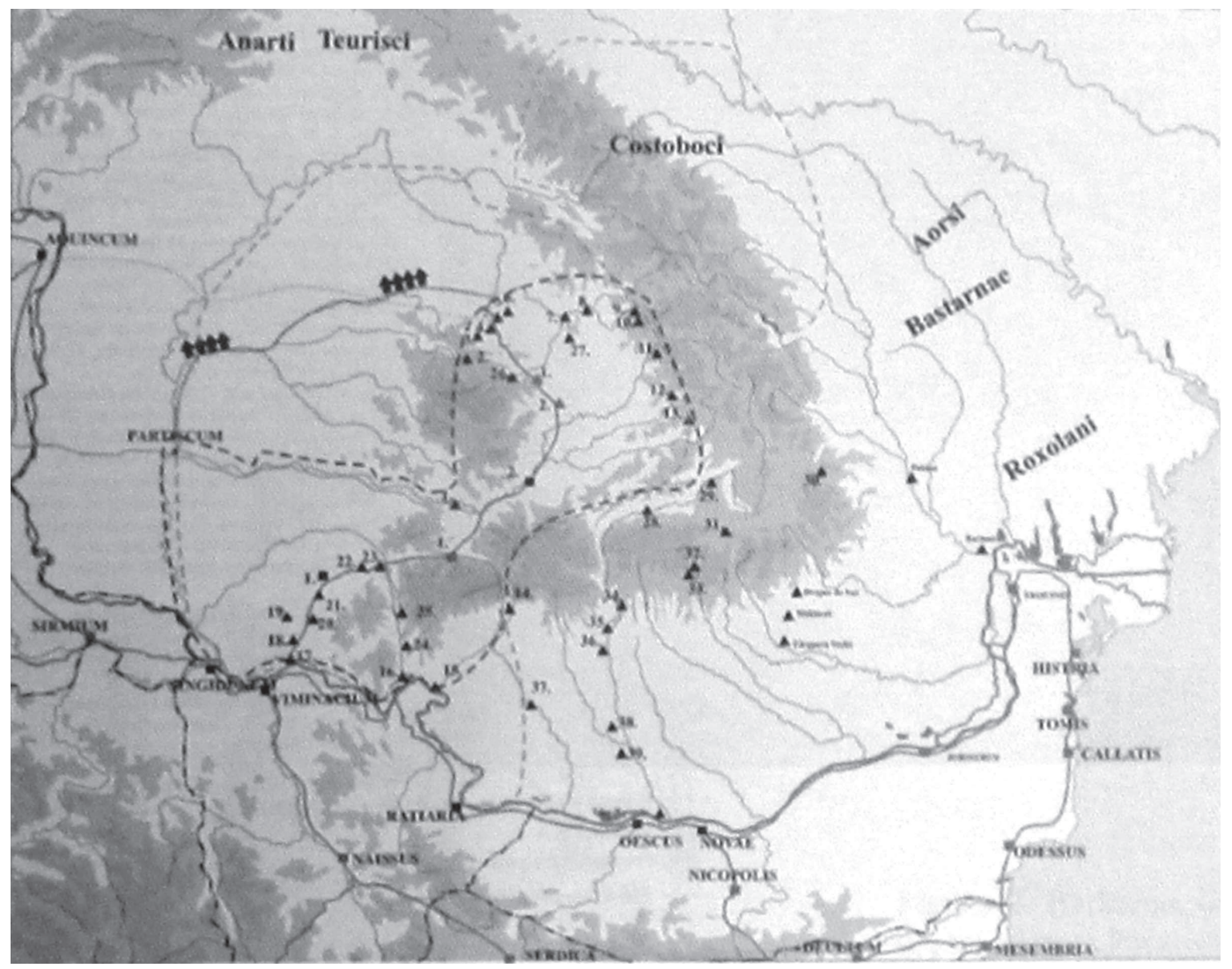

Opreanu 2011, fig. I. 


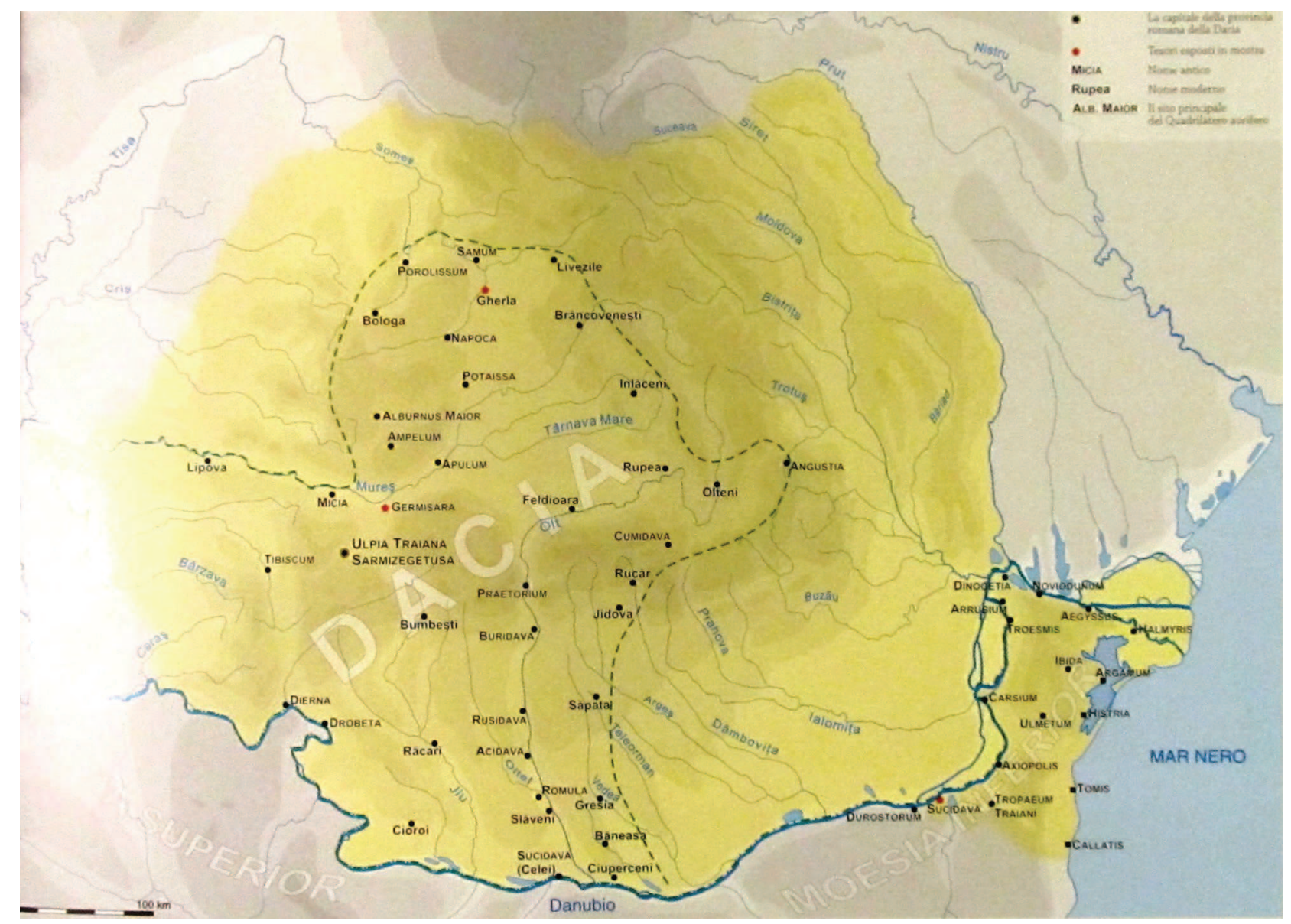

Marinescu 2010, 75.

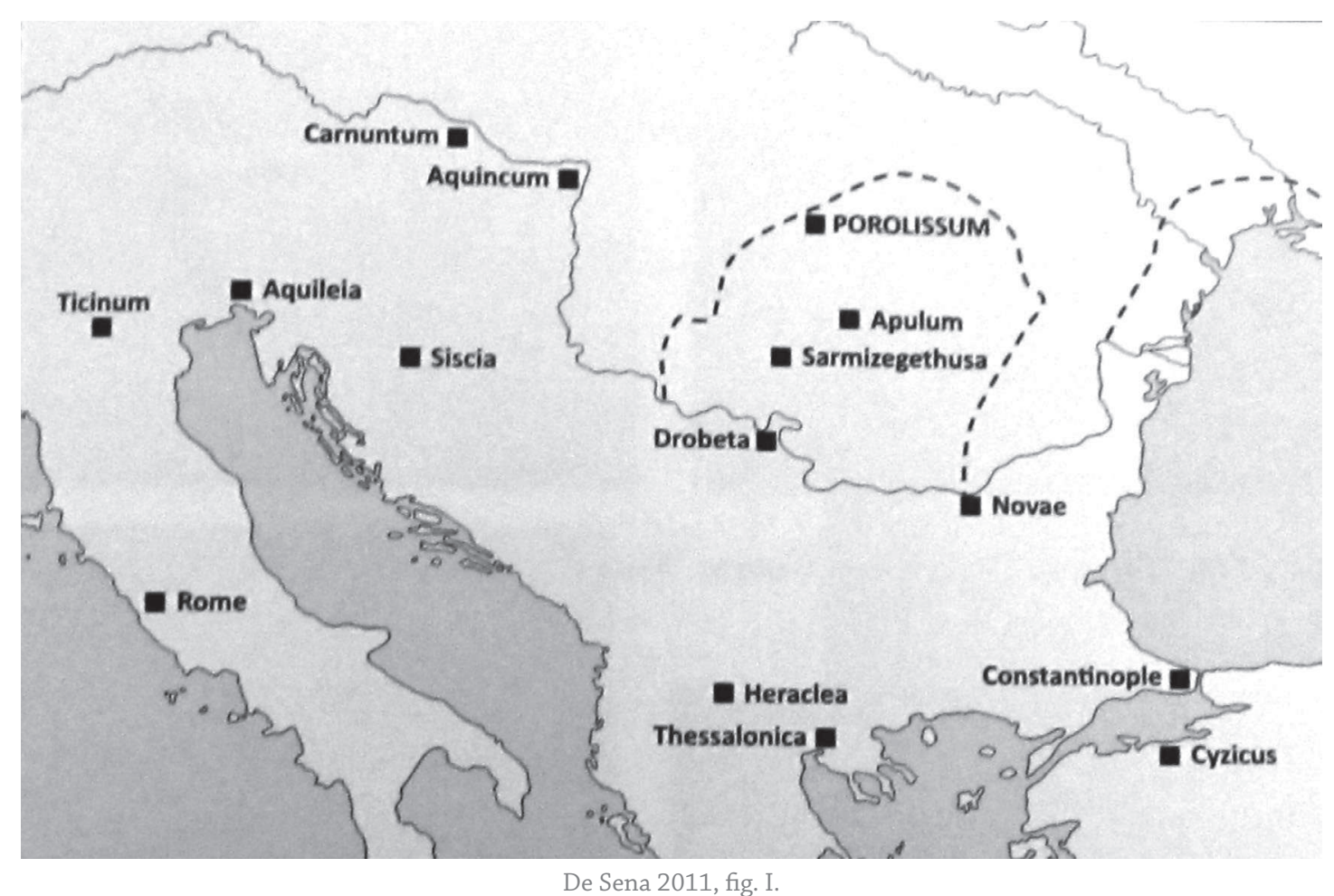




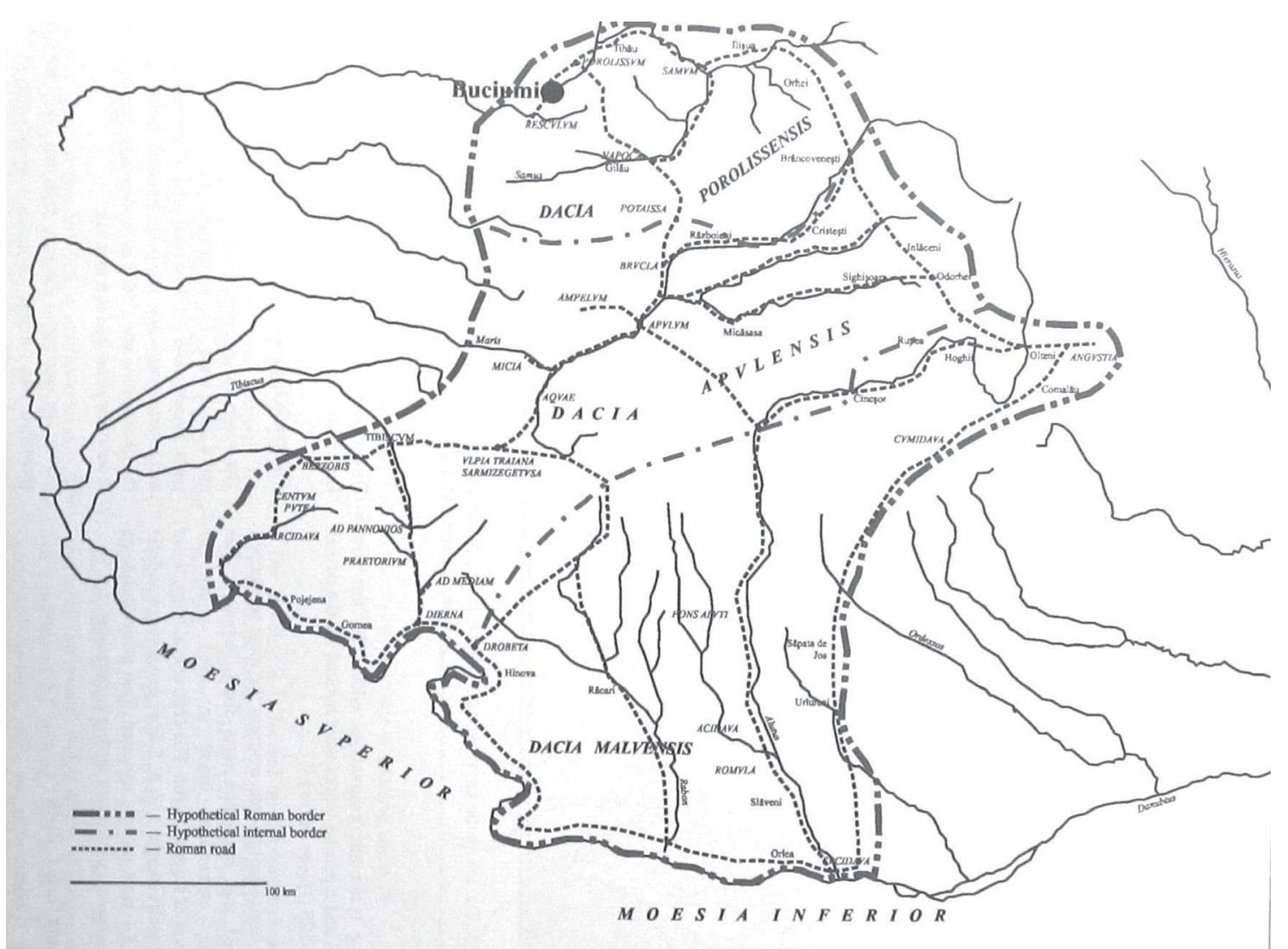

Găzdac 2012, fig. I.

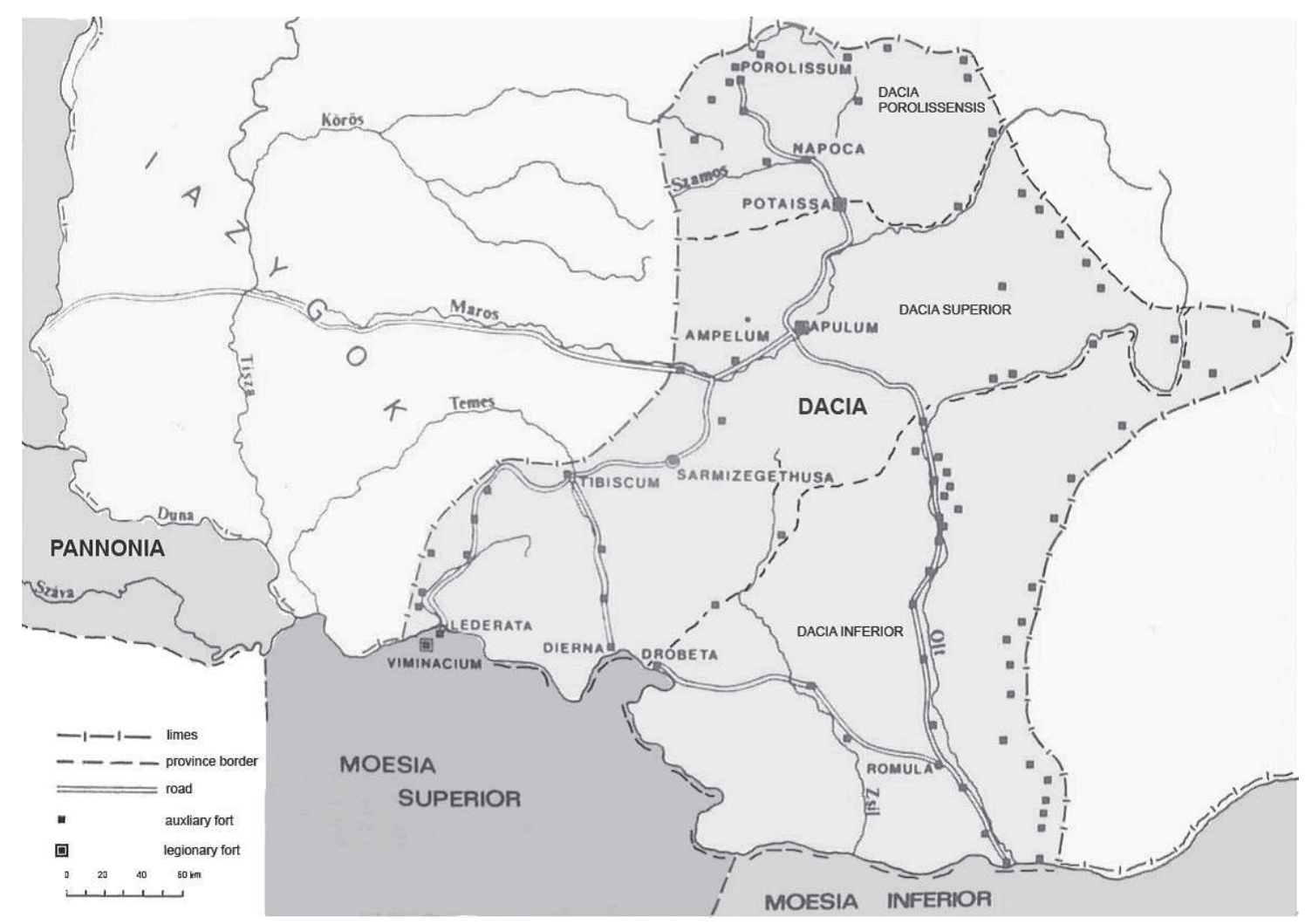

Visy 2010, 91. Fig. I. 